\title{
An assessment of El Niño and La Niña impacts focused on monthly and seasonal rainfall and extreme dry/precipitation events in mountain regions of Colombia and México
}

\author{
María Carolina Pinilla Herrera ${ }^{1,2}$ and Carlos Andrés Pinzón Correa ${ }^{2}$ \\ ${ }^{1}$ Centro de Investigaciones en Geografía Ambiental - UNAM, Morelia, México \\ ${ }^{2}$ Fundación Natura, Bogotá, Colombia \\ Correspondence to: María Carolina Pinilla Herrera (omsha_ra@yahoo.com)
}

Received: 3 December 2015 - Revised: 4 March 2016 - Accepted: 10 March 2016 - Published: 22 March 2016

\begin{abstract}
The influence of El Niño and La Niña on monthly and seasonal rainfall over mountain landscapes in Colombia and México was assessed based on the Oceanic Niño Index (ONI). A statistical analysis was develop to compare the extreme dry/precipitation events between El Niño, La Niña and Neutral episodes. For both areas, it was observed that El Niño and La Niña episodes are associated with important increases or decreases in rainfall. However, Neutral episodes showed the highest occurrence of extreme precipitation/dry events. For a better understanding of the impact of El Niño and La Niña on seasonal precipitation, we did a compound and a GIS analyses to define the high/low probability of above, below or normal seasonal precipitation under El Niño, La Niña and cold/warm Neutral episodes. In San Vicente, Colombia the below-normal seasonal rainfall was identified during El Niño and Neutral episodes in the dry season JJA. In this same municipality we also found above-normal seasonal rainfall during La Niña and Neutral episodes, especially in the dry season DJF. In Tancítaro México the below-normal seasonal rainfall was identified during La Niña winters (DJF) and El Niño summers (JJA), the above-normal seasonal rainfall was found during La Niña summers (JJA) and El Niño winters (DJF).
\end{abstract}

\section{Introduction}

El Niño and La Niña events have been studied exhaustively and they are associated with the interannual extreme rainfall variability, especially in the tropical and sub-tropical regions of the Pacific basin (Zambrano, 1986; Ropelewski and
Halpert, 1987; Philander, 1990; Allan et al., 1996; Manson and Goddard, 2001; Dewitte et al., 2013). The events of La Niña are associated with unusual cold temperatures in the equatorial Pacific Ocean, while El Niño is characterized by unusual high temperatures in the same region. Both of them have an important impact on precipitation patterns, which can increase or decrease the occurrence of extreme dry/precipitation events and therefore, affect primary economic activities such as fisheries and agriculture (Coelho and Goddard, 2009; Lavado-Casimiro et al., 2013; Jozami et al., 2015).

In Colombia, El Niño events increase the occurrence of extreme dry events over most the country, but especially from January to July in regions like the Caribbean and the Andes (Baldión and Guzmán, 1994; Guzmán and Baldión, 1997; Montealegre and Pabón, 2000; Poveda, 2004; Puerta and Carvajal, 2008; Ruíz and Pabón, 2013). On the other hand, La Niña increases the occurrence of extreme precipitation events from July to December with significant impacts on the Caribbean, the Andean and Amazonas (Cadena et al., 2006; Hurtado and González, 2012). Studies at regional level by Ramírez and Jaramillo (2009) and Poveda et al. (2001a, b) have reported different precipitation aspects during ENSO in the central mountain range of the country, known as central Andes; those studies found a prominent influence of ENSO on rainfall (decrease during El Niño and increase during La Niña) for DJF and JJA which are historically considered as the dry seasons.

Mexico exhibits a monsoonal climate with a rainy season during the summer months and a relatively dry (Escobar et al., 2001; Magaña et al., 2003; Pereyra et al., 2004). It 
has been demonstrated that El Niño events are related to intense droughts during spring and summer over the center and the south of the country, while Northern Mexico, the Pacific coast and the peninsula of Yucatan are exposed to rainfall in winter (Conde et al., 1997; Magaña et al., 2003). In the central and northern zones the cold fronts increase in winter, whereas summer droughts and fewer hurricanes are seen in the Caribbean and the Gulf of Mexico (Magaña, 1998; Badán, 2003; Granados et al., 2011). So, droughts in summer and cold fronts in winters are the meteorological events best known related to El Niño episodes (Magaña et al., 1998, 2003; Conde et al., 1997). For La Niña events in central Mexico has been reported intense droughts during winters and the increase of precipitation during summers. Nonetheless, Magaña et al. (2003) argued that the impact of El Niño and La Niña events on winter rainfall is not always the same. They attributed this to a southward shift of the Inter Tropical Convergence Zone (ITZC), more intense trade winds, a decreased number of tropical cyclones over the Intra Americas Seas (IAS) and reduced relative humidity, that may result in several and different regional/local patterns in the interseasonal climate variability related to ENSO.

There are significant advances in studies concerning the precipitation effects associated with ENSO and its impacts on extreme precipitation/dry events at national level and on both the Pacific coastal regions and the key coffee and maize cultivation zones in Columbia and Mexico (Magaña, 1998; Poveda et al., 2001a, b; Cadena et al., 2006; Conde and Saldaña, 2007; Puerta and Carvajal, 2008; Ramírez and Jaramillo, 2009; Granados et al., 2011; Ruíz and Pabón, 2013). Still, little is known about the impact of El Niño and La Niña events at local level in mountain landscapes, which are regions with relevant crop production and exposed to several climate variability processes. In particular, there are no studies about the influence of El Niño and La Niña on local seasonal precipitation over the mountainous northeast region of Colombia, which is the most important cocoa production area in the country. Similarly, no investigations have been done in the Purépecha Plateau of Mexico, the most important production area for avocados for export in México.

For both countries, several authors have recommended to include studies at regional or local scale for a better understanding of the influence of ENSO on monthly and seasonal rainfall patterns with socio-economic planning purposes (Montealegre and Pabón, 2000; Poveda, 2004; Ruíz and Pabón, 2013; Cadena et al., 2006; Conde and Saldaña, 2007; Nuñez and Treviño, 2013). This represents a challenge because climate information at local level is not accurate due to the low density of available meteorological/climate stations. However, data of monthly and seasonal rainfall are the only available data at local level and its analyses are relevant for perennial crop planning.

The aim of this study is to analyze how El Niño and La Niña episodes might affect the monthly and seasonal precipitation. We compared increases and decreases of extreme dry/precipitation events during ENSO and Neutral episodes. Additionally, we studied the probability of occurrence of seasonal precipitation between El Niño, La Niña and Neutral episodes. We consider that for mountain landscapes with important rural economies, this kind of climate information can be used for the development of strategies to improve crop production and resource management.

\section{Study locations and methods}

The municipality of San Vicente de Chucurí is located in the central-western region of Santander, Colombia between the eastern mountain range and the valley of the Magdalena river, with altitudes between 300 and $3200 \mathrm{~m}$ a.s.l. (Fig. 1). In addition to the orographic patterns, the trade winds and the yearmigration of the inter-tropical convergence zone (ITCZ) explain the local expression of the bimodal season in this region of Colombia. In San Vicente de Chucurí the annual precipitation varies from $1000 \mathrm{~mm}$ in the lowlands near the Magdalena Valley to $2500 \mathrm{~mm}$ in the higher mountain regions.

The municipality of Tancítaro, Michoacán state, is located in the physiographical province of the neo-volcanic axis of Mexico, specifically at sub- province of Tarasca, which is represented by volcanic mountain ranges with isolated volcanic strata, plains and basaltic plateaus (Fig. 2). Altitude is between 900 and $3200 \mathrm{~m}$ a.s.l. and the precipitation varies between 700 and $2000 \mathrm{~mm}_{\text {year }}{ }^{-1}$ depending on its orographic patterns and seasons. Since it is located in central western Mexico, this region reaches the minimum temperatures, medium humidity and droughts during the winter, while the most intense rainfalls and the highest temperatures and humidity occur mainly during the summer. Between June and November this region is exposed to tropical cyclones, which sometimes bring several rainfalls after the summer. In the highest altitudes, the temperature decrease around $-5^{\circ} \mathrm{C}$ between December and February, this may bring several freezing episodes. In the lowest altitudes the temperature could increase around $28^{\circ} \mathrm{C}$ during summer time.

This research was based on available meteorological information. In the case of San Vicente, Colombia, the study was done with monthly precipitation data from fifteen meteorological stations at the IDEAM (Instituto de Hidrología, Meteorología y Estudios Ambientales de Colombia) for a period comprising 1970-2010. For Tancítaro, Mexico, the study was carried out with monthly precipitation data from the Servicio Meteorológico Nacional (Base de Datos Climatológica Nacional), which compiles the information of eight different meteorological stations around Tancítaro, for a period comprising 1952-2012.

The methodological approach included: (i) the quality control of datasets, (ii) the use of the ONI Index to classify the monthly accumulated precipitation by El Niño, La Niña or cold/warm Neutral events, (iii) a statistical analysis to report the extreme dry/wet months by El Niño, La Niña 


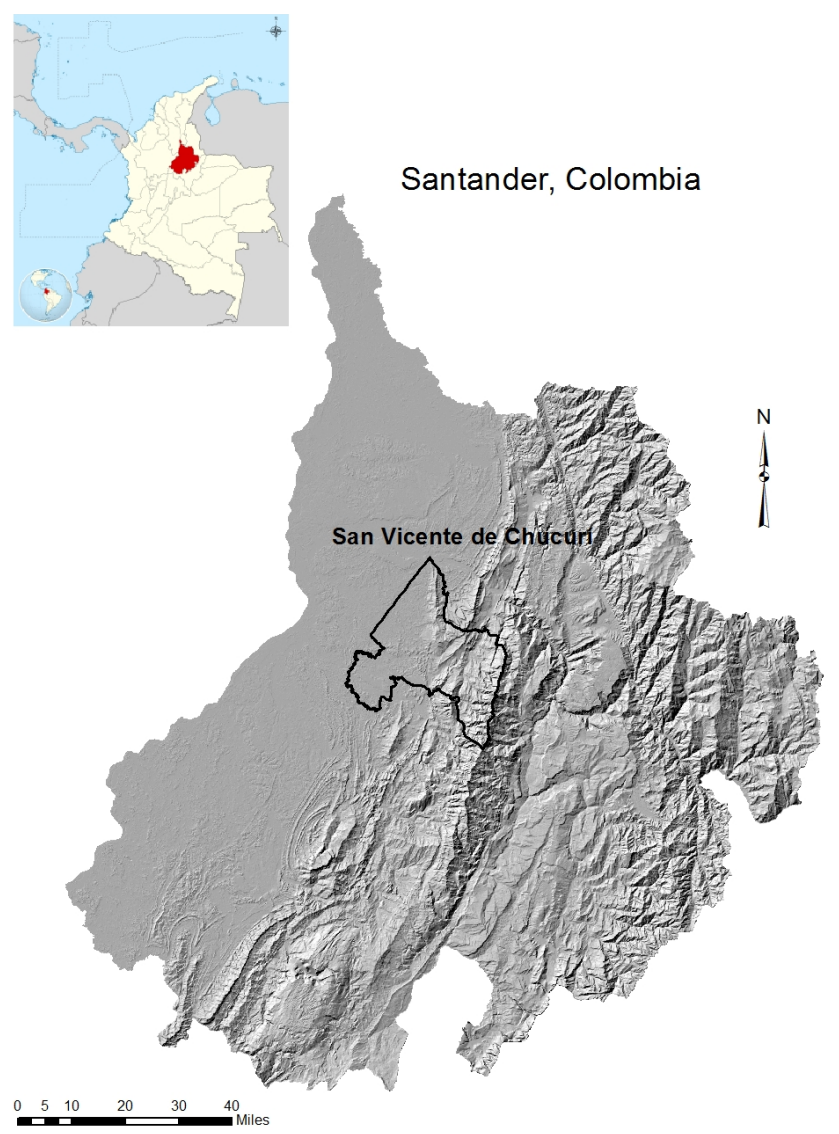

Figure 1. Location of Colombian study case, San Vicente de Chucuri. Source: Convenio 46/3379, Fundación Natura - ISAGEN.

or cold/warm Neutral events, and, (iv) a GIS-based geostatistical analysis of rainfall by El Niño, La Niña or cold/warm Neutral events per season.

For the quality control of datasets, the monthly accumulated precipitation records were homogenized using double mass cumulative techniques and missing data were filled by linear regression among stations, showing middle interstation cross correlations. We expected high variability in the data from some meteorological stations since some failures have been reported on several devices and also with the data collection in Colombian and México. For these reasons we accepted $P$ value $\alpha=0.10 / 0.20$ and we rejected the records of some meteorological stations if they had at least $25 \%$ of missing data (Valdivia et al., 2010, 2013), these included data from two meteorological stations in Colombia and one in México.

The data distribution and the months and years with rainfall anomalies could be identify using the box plot analysis. The precipitation effects associated with El Niño, La Niña or Neutral episodes per month, were determined using the ONI index (Ramírez and Jaramillo, 2009; NOAA, 2013), we also compared the historical and monthly average values (Jozami et al., 2015).

\section{Michoacán, México}

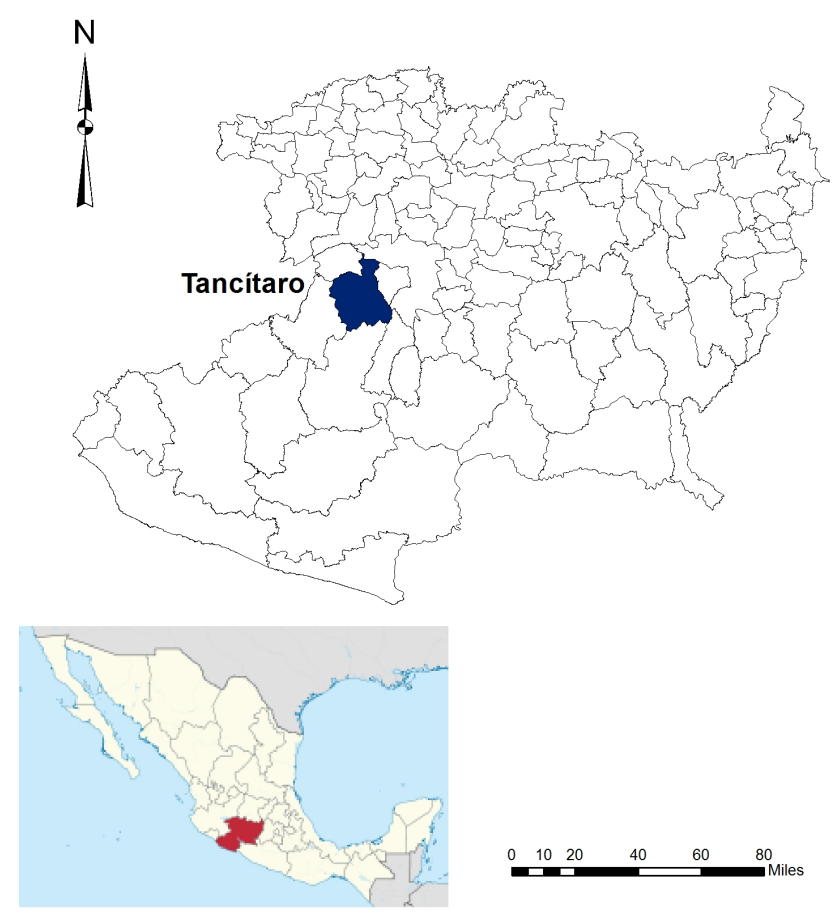

Figure 2. Location of Mexican study case, Tancítaro, México. Source: INEGI (2009).

The statistical analysis that reports the extreme dry/wet events was done using normalized differences and log transformation (Hamilton et al., 2012; Nuñez and Treviño, 2013), a comparison between the smaller number of El Niño-La Niña extreme episodes to the number of Neutral extreme episodes. For each month (classified by ONI index in El Niño, La Niña or Neutral episode) the precipitation values below 10th percentile (p10 dry extremes) and the precipitation values exceeding 90th percentile (p90 wet extremes) were identified and compared.

The GIS-based geostatistical analysis was based on:

a. The seasonal classification for both places:

i. December-January-February: first dry season of the year (Colombia)-Winter (Mexico).

ii. March-April-May: first rainy season (Colombia) Spring (Mexico).

iii. June-July-August: second dry season (Colombia) Summer (Mexico).

iv. September-October-November: second rainy season (Colombia) - Autumn (Mexico).

b. A compound analysis by relative frequency (\%) contingency tables per meteorological station was used to define the high/low probability of above, below or normal seasonal precipitation under El Niño, La Niña, 
cold/warm Neutral events (Alfaro and Soley, 2009; Fallas and Alfaro, 2012). We used the ONI Index values to define cold/warm phases for Neutral episodes for years with a TSM anomaly $-0.4{ }^{\circ} \mathrm{C}<T_{\text {dep }}<+0.4{ }^{\circ} \mathrm{C}$ (which represent a relevant cold/warm condition) but not called El Niño or La Niña itself.

c. The selection of meterological stations with Chisquared (X2) test: P value $\alpha=0.05 / \alpha=0.10 / \alpha=0.20$

d. Frecuency histograms and map development with inverse-distance-weighted interpolation.

\section{Results}

\subsection{San Vicente de Chucurí, Santander, Colombia}

It was obtained fifteen Box-Plot diagrams that showed the record of the meteorological stations with a bimodal regime: two rainfall seasons between by two dry seasons. The highest rainfalls are in MAM and SON; and dry seasons are in DJF and JJA. Figures 3 and 4 show just two samples of the BoxPlot diagrams with the bimodal regime and the months and years with atypical precipitation records.

The ONI value analysis allows us to select El Niño events. From 1970 onwards fourteen El Niño events have occurred and six of them showed the highest ONI values related to dry events. The most significant impact on the local monthly precipitation occurred on September and October (Table 1). On other hand, from 1970 onwards there were fifteen events of La Niña and six of them indicated the highest ONI values related to increase of precipitation. In those years the highest recorded values occurred on August and October (Table 2).

To analyze the information by extreme dry/wet events, all monthly records were normalized and linked to El Niño, La Niña or Neutral episodes. Figure 5 shows that the highest occurrence of extreme precipitation events (above the 90th percentile) were registered during Neutral episodes. La Niña episodes, showed extreme precipitation events too but only in a few meteorological stations. The lowest occurrence of extreme precipitation events were during El Niño episodes. Checking the dataset, we found that months with more extreme precipitation events reported were August (on Neutral and La Niña episodes), October (on Neutral and La Niña episodes) and November (on Neutral and La Niña episodes). So, the extreme precipitation events during $\mathrm{La}$ Niña or Neutral episodes occurred mainly in August, October and November.

The highest occurrence of extreme dry events (below the 10th percentile) were reported also in Neutral episodes, but with high dispersal data. Extreme dry events occurred less frequently in El Niño and even less in La Niña episodes (Fig. 6). The months with more extreme dry events reported were September (on Neutral and El Niño episodes) and October (on Neutral and El Niño episodes). Therefore, the ex-

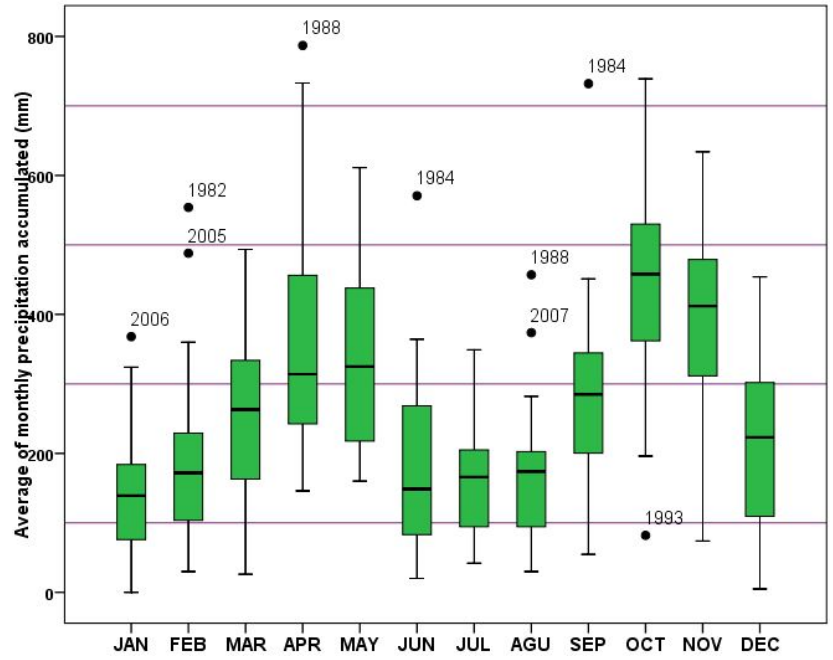

Figure 3. Monthly variability of precipitation (mm) at Puente La Paz meteorological station (1979-2010).

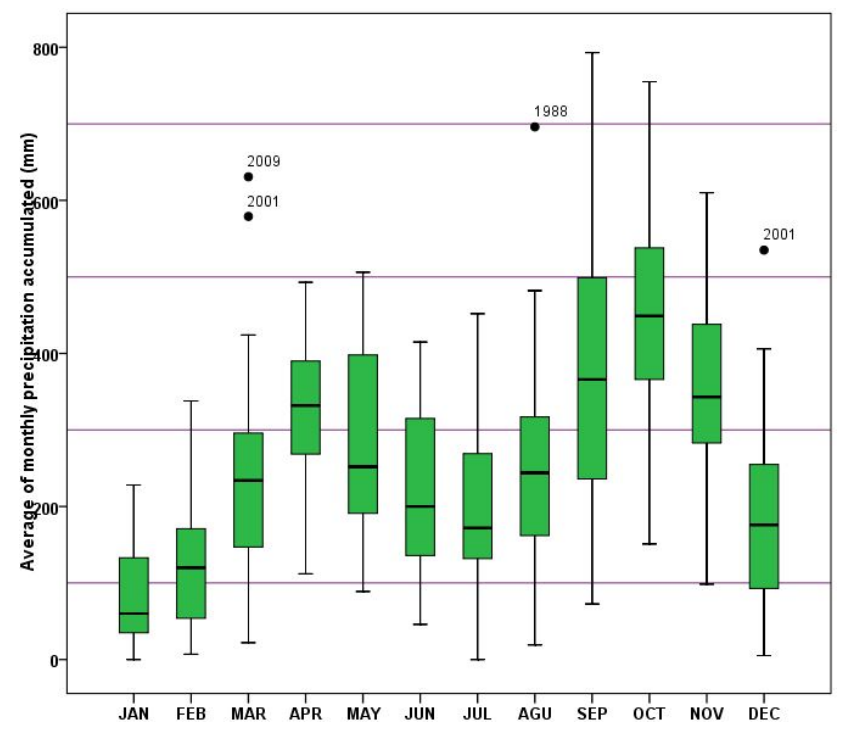

Figure 4. Monthly variability of precipitation $(\mathrm{mm})$ at La Putana meteorological station (1973-2010).

treme dry events during El Niño or Neutral episodes occurred mainly in September and October.

As mentioned before, the compound analysis gave us the possibility to establish the high/low probability of above, below or normal seasonal precipitation under El Niño, La Niña, cold/warm Neutral episodes. The GIS-based analysis of these probabilities was done by frequency histograms and maps and both interpretations showed the same result. In this manuscript the Colombian case is only represented by the frequency histograms.

Figure 7 shows the probabilities of occurrence of abovenormal, normal, and below-normal seasonal precipitation during El Niño, La Niña and cold/warm Neutral episodes. 
Table 1. Comparison of the climatological monthly mean value vs. the precipitation value under El Niño episodes.

\begin{tabular}{|c|c|c|c|c|c|}
\hline Meteorological station/month & $\begin{array}{r}\text { Climatological monthly } \\
\text { mean value }\end{array}$ & $\begin{array}{l}\text { El Niño } \\
\text { episode }\end{array}$ & $\begin{array}{r}\text { ONI } \\
\text { value }\end{array}$ & $\begin{array}{l}\text { Precipitation value under } \\
\text { El Niño episode }\end{array}$ & $\begin{array}{l}\text { SE of } \\
\text { the mean }\end{array}$ \\
\hline Lebrija, September & $130 \mathrm{~mm}$ & September, 1972 & 1.6 & $65 \mathrm{~mm}$ & 0.33 \\
\hline Zapatoca, October & $75 \mathrm{~mm}$ & October, 1973 & 1.8 & $38 \mathrm{~mm}$ & 0.19 \\
\hline Girón, September & $90 \mathrm{~mm}$ & September, 1982 & 1.9 & $20 \mathrm{~mm}$ & 0.35 \\
\hline Betulia, October & $450 \mathrm{~mm}$ & October, 1991 & 1.4 & $80 \mathrm{~mm}$ & 1.85 \\
\hline Lebrija, September & $145 \mathrm{~mm}$ & September, 1997 & 2.1 & $70 \mathrm{~mm}$ & 0.38 \\
\hline San Vicente de Chucurí, October & $280 \mathrm{~mm}$ & October, 2009 & 1.1 & $40 \mathrm{~mm}$ & 1.2 \\
\hline
\end{tabular}

SE: standard error.

Table 2. Comparison of the climatological monthly mean value vs. the precipitation value under La Niña episodes.

\begin{tabular}{|c|c|c|c|c|c|}
\hline Meteorological station/month & $\begin{array}{r}\text { Climatological monthly } \\
\text { mean value }\end{array}$ & $\begin{array}{l}\text { La Niña } \\
\text { episode }\end{array}$ & $\begin{array}{l}\text { ONI } \\
\text { value }\end{array}$ & $\begin{array}{r}\text { Precipitation value under } \\
\text { La Niña episode }\end{array}$ & $\begin{array}{r}\text { SE of } \\
\text { the mean }\end{array}$ \\
\hline San Vicente de Chucurí, October & $240 \mathrm{~mm}$ & October, 1970 & -0.8 & $580 \mathrm{~mm}$ & 1.7 \\
\hline Girón, November & $170 \mathrm{~mm}$ & November, 1974 & -0.9 & $710 \mathrm{~mm}$ & 2.7 \\
\hline Zapaptoca, August & $100 \mathrm{~mm}$ & August, 1998 & -1.0 & $275 \mathrm{~mm}$ & 0.88 \\
\hline Los Santos, August & $28 \mathrm{~mm}$ & August, 1999 & -1.1 & $115 \mathrm{~mm}$ & 0.44 \\
\hline Lebrija, October & $145 \mathrm{~mm}$ & October 2007 & -1.5 & $325 \mathrm{~mm}$ & 0.9 \\
\hline Betulia, October & $420 \mathrm{~mm}$ & October 2011 & -0.8 & $790 \mathrm{~mm}$ & 1.85 \\
\hline
\end{tabular}

SE: standard error.

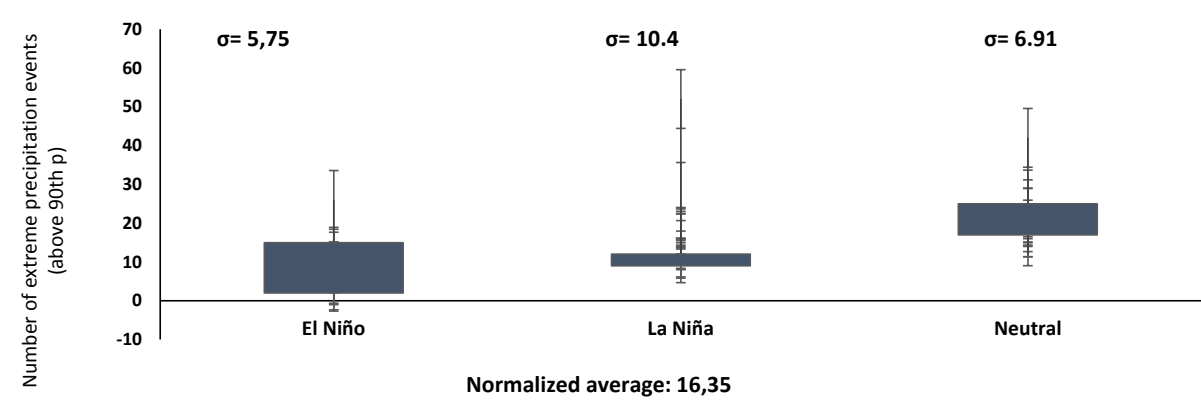

Figure 5. Normalized data of extreme precipitation events (above the 90th percentile) recorded in all meteorological stations around San Vicente de Chucurí, Colombia. Source: IDEAM.

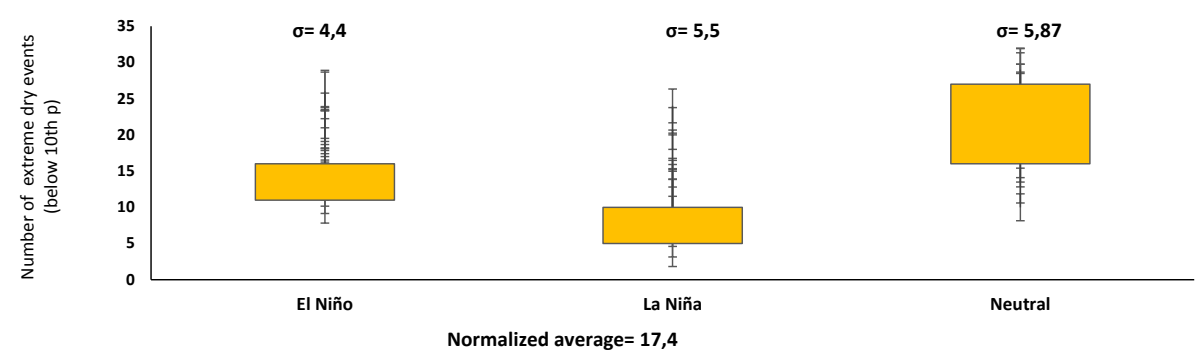

Figure 6. Normalized data of extreme dry events (below the 10th percentile) recorded in all meteorological stations around San Vicente de Chucurí, Colombia. Source: IDEAM.

The highest occurrence of the above-normal seasonal precipitation is in quarters DJF during La Niña and cold Neutral episodes (probabilities of 50 and $70 \%$ ) and JJA, SON in La Niña episodes (probabilities of 50 and $70 \%$ ). The highest oc- currence of the below-normal seasonal precipitation is in JJA during El Niño (probabilities of 50 and $70 \%$ ), followed by SON during El Niño (probabilities of 50 and 70\%) and neutral cold episodes (probabilities of 30 and $50 \%$ ). The quar- 


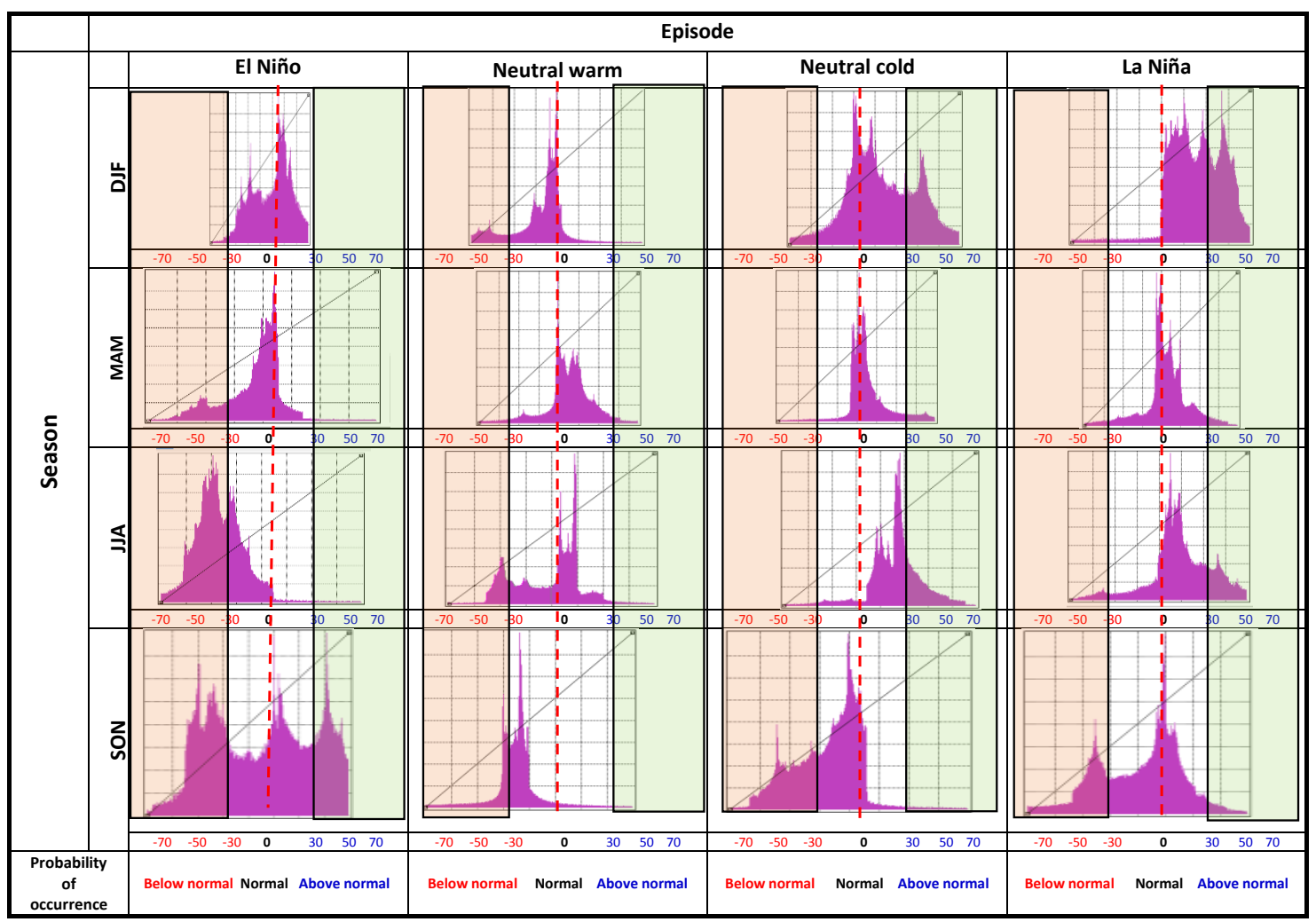

Figure 7. Histograms of probability of occurrence $(\%)$ of above-normal, normal, and below-normal seasonal precipitation during El Niño, La Niña and cold/warm Neutral episodes in Santander, Colombia. $\alpha=0.20$ (4 meteorological stations for MAM; 3 meteorological stations for SON). $\alpha=0.10$ (8 meteorological stations for MAM and 10 meteorological stations for SON, DJF, JJA). $\alpha=0.05$ (5 meteorological stations for DJF and JJA).

ter MAM has the highest occurrence of the normal seasonal precipitation during El Niño, La Niña or cold/warm Neutral episodes.

This GIS-based analysis of rainfall reported a middle statistical significance because ten meteorological stations had $\alpha=0.10$ for quarters SON, DJF and JJA. The highest statistical significance was obtained for quarters DJF, JJA and MAM $(\alpha=0.05)$ just in four meteorological stations. However, this geostatistical approach can be accepted to analyze historical records with at least $25 \%$ of missing data (Valdivia et al., 2013).

Baldión and Guzmán (1994) as well as Puerta and Carvajal (2008) reported above-normal seasonal precipitation only in rainy seasons during La Niña events for the Caribbean and Andean zones. But our findings show that local precipitation in the mountainous northeast region of Colombia can significantly increase during dry seasons (especially on DJF) in La Niña episodes, as well as during rainy seasons in Neutral or La Niña episodes.

For the Caribbean region some works (Guzmán and Baldión, 1997; Ruíz und Pabón, 2013) described an important decrease in precipitation for DJF and JJA during ENSO (mainly El Niño episodes). Our results also reported a high probability of occurrence of below-normal precipitation in those dry seasons during El Niño episodes. However, we found the same signal of below-normal seasonal precipitation for Neutral episodes.

The above-normal precipitation raifall in DJF during La Niña or cold Neutral episodes is especially critical for the emergency of diseases in the cocoa. The incidence of fungi such as Monilia sp. or Phytoptora sp. could increase and affect the most important harvest time of the year. The flowering cycles of the cocoa can also be affected by drought in JJA during El Niño events. If this information could be given to farmers and local institutions, they could develop strategies for fungi or crop management such as a frequent harvest of infected fruits or timely fumigations.

\subsection{Tancítaro, Michoacán, Mexico}

All the Box-Plot diagrams showed a monomodal regime characterized by a rainy season between May and October and a dry season between November and April. Figures 8 and 9 show just two samples of the Box-Plot diagrams with the monomodal regime and the months and years with atypical precipitation records. 
Table 3. Comparison of the climatological monthly mean value vs. the precipitation value under El Niño episodes.

\begin{tabular}{|c|c|c|c|c|c|}
\hline Meteorological station/month & $\begin{array}{r}\text { Climatological monthly } \\
\text { mean value }\end{array}$ & $\begin{array}{l}\text { El Niño } \\
\text { episode }\end{array}$ & $\begin{array}{r}\text { ONI } \\
\text { value }\end{array}$ & $\begin{array}{r}\text { Precipitation value under } \\
\text { El Niño episode }\end{array}$ & $\begin{array}{r}\text { SE of } \\
\text { the mean }\end{array}$ \\
\hline Los Chorros de Varal, May & $87 \mathrm{~mm}$ & May, 1998 & 2.3 & $0 \mathrm{~mm}$ & 0.44 \\
\hline Los Chorros, Jun & $125 \mathrm{~mm}$ & May, 1992 & 1.8 & $25.8 \mathrm{~mm}$ & 0.5 \\
\hline Charapendo, July & $99 \mathrm{~mm}$ & July, 1972 & 1.9 & $11.5 \mathrm{~mm}$ & 0.44 \\
\hline Tanaco, August & $49 \mathrm{~mm}$ & August, 2010 & 1.7 & $9.5 \mathrm{~mm}$ & 0.24 \\
\hline Los Chorros, November & $20 \mathrm{~mm}$ & November, 1977 & 1.6 & $127 \mathrm{~mm}$ & 0.54 \\
\hline Paracuaro, December & $4.6 \mathrm{~mm}$ & December, 1987 & 1.7 & $18 \mathrm{~mm}$ & 0.07 \\
\hline Acahuato, January & $19.5 \mathrm{~mm}$ & January, 2009 & 1.6 & $199 \mathrm{~mm}$ & 0.9 \\
\hline Uruapan, January & $46.8 \mathrm{~mm}$ & January, 1995 & 1.6 & $610 \mathrm{~mm}$ & 2.82 \\
\hline Uruapan, February & $9.9 \mathrm{~mm}$ & February, 1973 & 1.8 & $166.8 \mathrm{~mm}$ & 0.78 \\
\hline
\end{tabular}

SE: standard error.

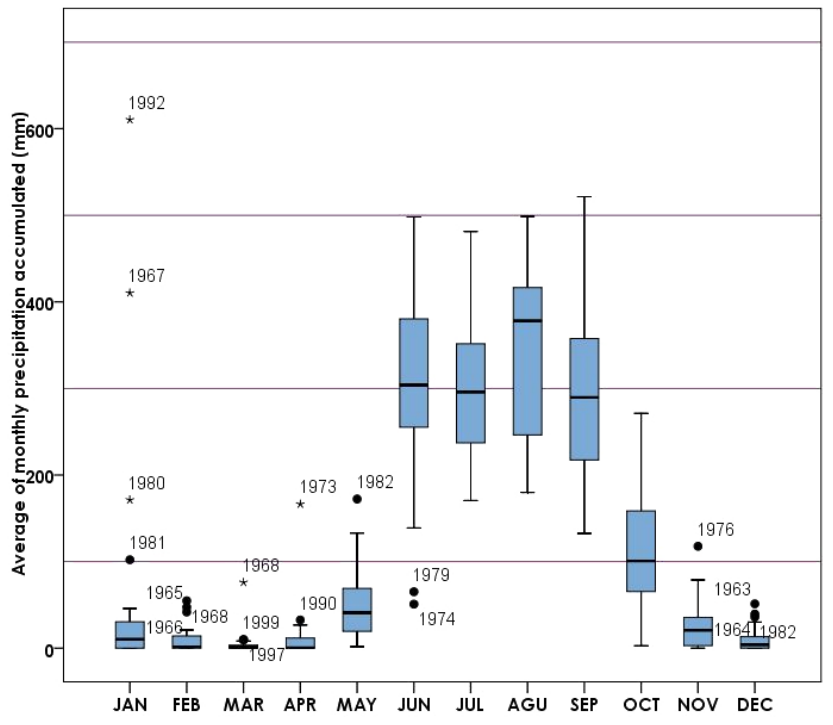

Figure 8. Monthly variability of precipitation ( $\mathrm{mm}$ ) at Uruapan meteorological station (1962-1999).

Based on ONI Index we found precipitation increase by the strongest El Niño episodes during December, January and February, while May, Jun, July and August have been affected by a precipitation decrease (Table 3). During the strongest La Niña episodes, rainfalls between December and February showed a decrease and rainfalls from May to July showed an increase (Table 4).

The number of extreme dry/wet events recorded by monthly scale is shown in Fig. 10. The highest occurrence of extreme precipitation events (above the 90th percentile) were registered during in Neutral episodes, but the data series is highly dispersed. El Niño episodes had a fewer extreme precipitation events and La Niña had even less. Cheking all datasets, months with more extreme precipitation events reported were May and June on Neutral episodes and, December and February on El Niño episodes.

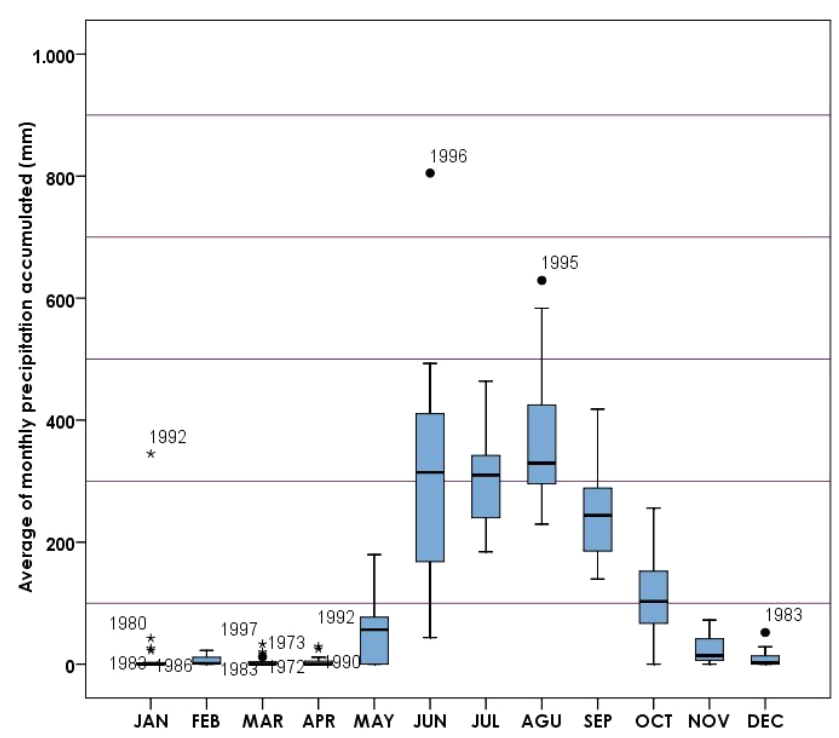

Figure 9. Monthly variability of precipitation (mm) at Peribán meteorological station (1969-1998).

The highest occurrence of extreme dry events (below the 10th percentile) also were reported in Neutral episodes, but data dispersal is high (Fig. 11). Moreover the occurrence could change from one meteorological station to another depending on local conditions (such as orographical factors). The low dispersal data of La Niña events suggests that extreme dry events can affect the region and surroundings in a similar way. Months with more extreme dry events reported were January and February in Neutral episodes and May and June in La Niña ones.

The GIS-based analysis of the high/low probability of above, below or normal seasonal precipitation under El Niño, La Niña, cold/warm Neutral episodes for Tancítaro will be presented through probability maps (Fig. 12). The highest occurrence of the above-normal seasonal precipitation is in JJA during La Niña episodes (probabilities of 30 and 50\%) and MAM during cold Neutral episodes (probabilities of 30 
Table 4. Comparison of the climatological monthly mean value vs. the precipitation value under La Niña episodes.

\begin{tabular}{|c|c|c|c|c|c|}
\hline Meteorological station/month & $\begin{array}{r}\text { Climatological monthly } \\
\text { mean value }\end{array}$ & $\begin{array}{l}\text { La Niña } \\
\text { episode }\end{array}$ & $\begin{array}{r}\text { ONI } \\
\text { value }\end{array}$ & $\begin{array}{r}\text { Precipitation value under } \\
\text { La Niña episode }\end{array}$ & $\begin{array}{r}\text { SE of } \\
\text { the mean }\end{array}$ \\
\hline Chorros de Varal, May & $37.6 \mathrm{~mm}$ & May, 1988 & -1.8 & $112.9 \mathrm{~mm}$ & 0.38 \\
\hline Acahuato, May & $23.5 \mathrm{~mm}$ & May, 2000 & -1.6 & $103 \mathrm{~mm}$ & 0.4 \\
\hline Paracuaro, June & $170 \mathrm{~mm}$ & June, 1976 & -1.9 & $509 \mathrm{~mm}$ & 1.7 \\
\hline Charapendo, July & $243 \mathrm{~mm}$ & July, 1985 & -1.7 & $524 \mathrm{~mm}$ & 1.41 \\
\hline Uruapan, August & $221 \mathrm{~mm}$ & August, 1999 & -1.5 & $484 \mathrm{~mm}$ & 1.32 \\
\hline Uruapan, December & $11.4 \mathrm{~mm}$ & December, 1999 & -18 & $0 \mathrm{~mm}$ & 0.06 \\
\hline Periban, January & $21.7 \mathrm{~mm}$ & January, 1988 & -1.7 & $0 \mathrm{~mm}$ & 0.11 \\
\hline Acahuato, February & $9.9 \mathrm{~mm}$ & February, 2011 & -1.4 & $0 \mathrm{~mm}$ & 0.05 \\
\hline
\end{tabular}

SE: standard error.

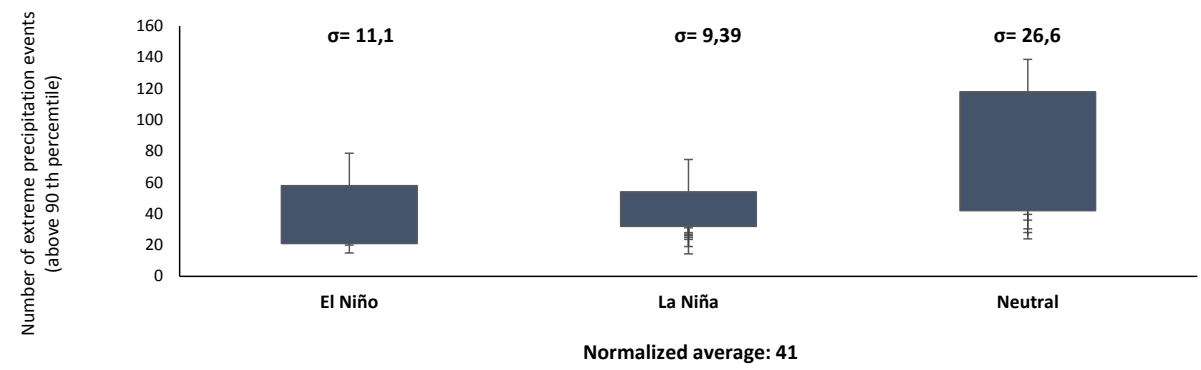

Figure 10. Normalized data of all extreme precipitation events (above the 90th percentile) in Tancítaro, Michoacán, Mexico. Source: Base de Datos Climatológica Nacional, SMN.

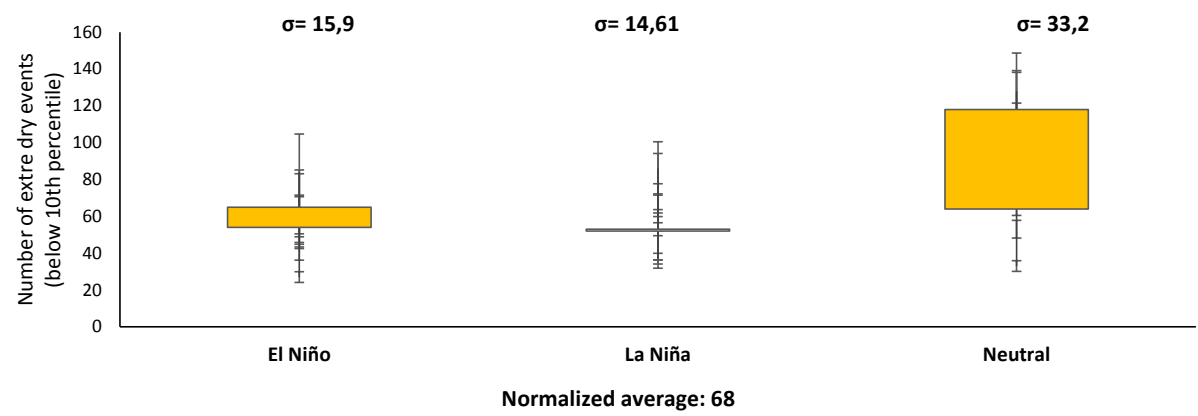

Figure 11. Normalized data of all extreme dry events (above the 10th percentile) in Tancítaro, Michoacán, Mexico. Source: Base de Datos Climatológica Nacional, SMN.

and $50 \%$ ). During La Niña episodes the occurrence of the below-normal seasonal precipitation is in quarters DJF and MAM (probabilities of 30 and $50 \%$ ). The highest occurrence of the normal seasonal precipitation is in quarters MAM during El Niño and warm Neutral, and SON during El Niño and La Niña episodes.

This GIS-based analysis of rainfall for Tancítaro reported a better statistical significance for quarters DJF and JJA because six meterological stations had $\alpha=0.05$, six meterological stations had $\alpha=0.10$ for quarter SON and five meterological stations had $\alpha=0.10$ for quarter MAM.

Several authors had reported an increase of precipitation during El Niño winters and La Niña summers, and a decrease of precipitation in El Niño springs and La Niña winters for Central and southern México, for the state of Baja California and for the City of Tabasco (Magaña, 1998; Mosiño and Morales, 1998; Reyes and Troncoso, 2001; Pereyra et al., 2004). Our findings showed that the mountainous landscapes in the meseta Tarasca (Michoacán) follow this same signal in El Niño and La Niña episodes. However, we also found the occurrence of above-normal and below-normal seasonal precipitation for DJF and MAM in Neutral episodes.

The above-normal and the below-normal seasonal precipitation in quarter MAM during cold Neutral and La Niña episodes, respectively, are especially critical for the avocado production. These months are essential to complete the flow- 


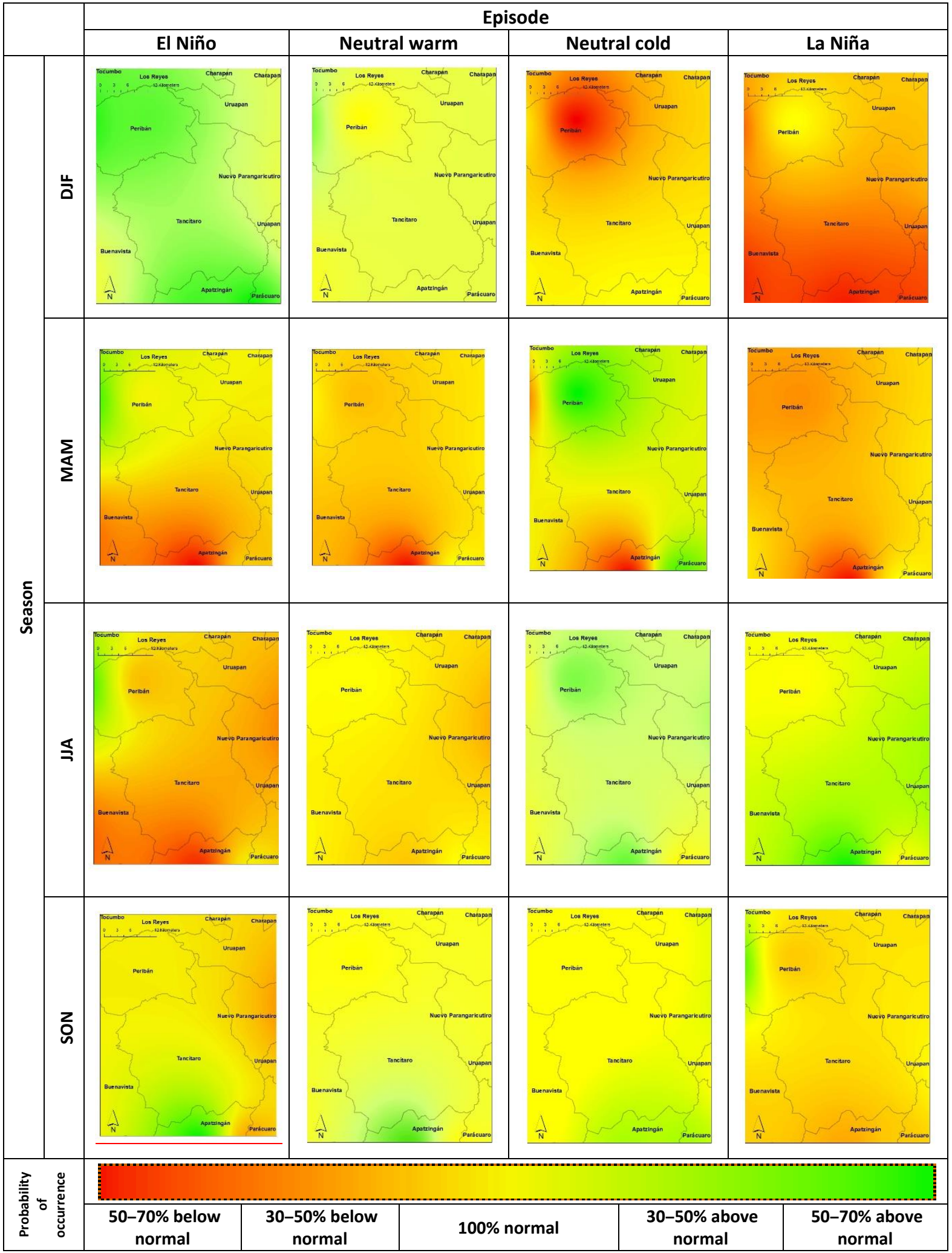

Figure 12. Maps of probability of occurrence (\%) of above-normal, normal, and below-normal seasonal precipitation in El Niño, La Niña and cold/warm Neutral epidodes in Tancítaro, Mexico. $\alpha=0.20$ (3 meteorological stations for MAM; 2 meteorological stations for SON). $\alpha=0.10$ (5 meteorological stations for MAM, 6 meteorological stations for SON and 2 meteorological stations for DJF, JJA). $\alpha=0.05$ (6 meteorological stations for DJF and JJA). 
ering cycle and particularly for a local flowering episode called "La Loca", which is very important for farmers from lowlands in Tancítaro. With this information, the farmers can accomplish a timely crop irrigation and take actions against flower losses (there is local knowledge of several techniques).

\section{Conclusions and perspectives}

This study has shown the impacts of El Niño and La Niña episodes on local monthly and seasonal precipitation in both locations. The results are in agreement with other researches done at a national level and in different regions. However, our data adds new information concerning the occurrence of extreme dry/precipitation events and the probabilities of belownormal, above normal or normal seasonal rainfall in Neutral episodes.

We were able to recognized that in those mountainous regions, as mentioned Magaña et al. (2003), that ENSO impact can be sometimes weaker than intra-annual seasonality due to the local orographic factors, the intensity of hurricanes and tropical cyclone over the Intra Americas Seas (IAS), cold fronts, trade winds and the southward shift of the of ITZC. The study of precipitation effects associated with ENSO in mountain landscapes can be improved by analysis conducting within different elevation ranges like was presented by Pineda et al. (2013).

Agricultural institutions and farmers can benefit from this scientific information to identify climate risks on farms. If all agricultural stakeholders could be convinced to work together they may develop a wide-range of anticipatory and reactive management strategies in response to economic losses due to climate.

Local information about climate data is important, however, as we have seen in this study there can be a middle statistical uncertainty due to technical failures and unreliable data collection at meteorological stations. To overcome these barriers we need more state-of-the art methodology and devices to provide additional and accurate local climate variability data.

For a suitable climate risk management (like phytosanitary warnings) it is also necessary to understand the perception of farmers on climate variability and climate risks, and also how they respond to the impact caused by climatic conditions.

\section{Data availability}

Climate data from this research are public accessible information from Instituto de Hidrología, Meteorología y Estudios Ambientales de Colombia (IDEAM) and Servicio Meteorológico Nacional. Databases from Santader, Colombia and Michoacán, México were purchased by projects; the information is property of ISAGEN-Fundación Natura and Centro de Investigaciones en Geografía Ambiental.
Author contributions. María Carolina Pinilla, Ecologist-PhD Candidate in Geography, designed the research, reviewed the methodological approach and results, prepared the manuscript and directed revisions in Spanish/English languages. Carlos Andrés Pinzón, Physicist-MSc., compiled data, conducted the statistical analysis and drafted the methodology and results.

Acknowledgements. The authors would like to recognize the total support of the following projects during this research: Convenio 46/3379 Fundación Natura Colombia-ISAGEN E.S.P.: "Programa para atender la percepción de la comunidad acerca de posibles cambios microclimáticos ocasionados por el embalse", and PAPIIT-UNAM IA300413 "Evaluación de la adaptación al cambio climático en comunidades rurales a través de su capacidad de respuesta en diferentes contextos geográficos en el estado de Michoacán". Special thanks to the Academic Writing team from UNAM Posgrado. The authors are grateful to Dra. María Pilar Cornejo and one anonymous reviewer whose valuable comments led us to the improvement of the different stages of this work.

Edited by: J. D. Pabón-Caicedo

Reviewed by: M. del Pilar Cornejo de Grunauer and one anonymous referee

\section{References}

Alfaro, E. and Soley, J.: Descripción de dos métodos de rellenado de datos ausentes en series de tiempo meteorológicas, Revista de Matemática: teoría y aplicaciones, 16, 60-75, 2009.

Alfaro, E., Soley, J., and Enfield, D.: Uso de una Tabla de Contingencia para Aplicaciones Climáticas, ESPOL publication, Guayaquil, Ecuador, 51 pp., 2003.

Allan, R., Lindsey, J., and Parker, D.: El Niño Southern Oscillation and climate variability, CSIRO Publication, 405 pp. 1996.

Badán, A.: The effects of El Niño in Mexico: A survey, Geofísica Internacional, 42, 567-571, 2003.

Baldión, J. and Guzmán, O.: Condiciones climáticas en la zona cafetera en los años 1991, 1992 y 1993 y su influencia en las cosechas de café, Cenicafe Avances Técnicos: 1-8, 1994.

Cadena, M., Pabón, J. D., Devis, A., Malikov, I., Reyna, J., and Ortiz, J.: Relationship Between the 1997/1998 El Niño and 1999/2001 La Niña Events and Oil Palm Tree Production in Tumaco, Southwestern Colombia, Adv. Geophysis, 6, 195-199, 2006.

Coelho, C. and Goddard, L.: El Niño-Induced Tropical Droughts in Climate Change Projections, J. Climate, 22, 6456-6476, 2009.

Conde, C. and Saldaña, S.: Cambio climático en América Latina y el Caribe: Impactos, vulnerabilidad y adaptación, Rev. Ambiente y Desarrollo, 23, 23-30, 2007.

Conde, C., Liverman, D., Flores, M., Ferrer, R., Araujo, R., Betancourt, E., Villareal, G., and Gay, C.: Vulnerability of rainfed maize crops in Mexico to climate change, Climate Change, 9, 17-34, 1997.

Dewitte, B., Bourrel, L., and Ambrizzi, T.: Editorial, Adv. Geosci., 33, 1-1, doi:10.5194/adgeo-33-1-2013, 2013. 
Escobar, E., Bonilla, M., Badán, A., Caballero M., and Winckell, A.: Los Efectos del Fenómeno de El Niño en México, 19971998, 245 pp., 2001.

Fallas, B. and Alfaro, E.: Uso de herramientas estadísticas para la predicción estacional del campo de precipitación en América Central como apoyo a los Foros Climáticos Regionales - 1: Análisis de tablas de contingencia, Revista de Climatología, 12, 61-79, 2012.

Granados, R., Aguilar, G., Díaz, G., and Medina, M.: Alteraciones de los indicadores agroclimáticos en años con presencia del fenómeno El Niño en la región centro-occidente de México, Rev. Geográfica de América Central, 1-16, 2011.

Guzmán, O. and Baldión, J.: El evento cálido del Pacifico en la zona cafetera Colombiana, Cenicafe, 48, 141-155, 1997.

Hamilton, E., Eade, R., Graham, R., Scaide, A., Smith, D., Maidens, A., and MacLachlan, C.: Forecasting the number of extreme daily events on seasonal timescales, J. Geophys. Res., 117, D03114, doi:10.1029/2011JD016541, 2012.

Hurtado, G. and González, O.: Evaluación de la afectación territorial de los fenómenos El Niño/La Niña y análisis de la confiabilidad de la predicción climática basada en la presencia de un evento. Instituto de Hidrología, Meteorología y Estudios Ambientales de Colombia, 38 pp., 2012.

Jozami, E., Constanzo, M., and Coronel, A.: Influencia de "El NiñoOscilación Sur" sobre las precipitaciones en Paraná y Lucas González (Entre Ríos, Argentina), Revista de Climatología, 15, 85-92, 2015.

Lavado-Casimiro, W. S., Felipe, O., Silvestre, E., and Bourrel, L.: ENSO impact on hydrology in Peru, Adv. Geosci., 33, 33-39, doi:10.5194/adgeo-33-33-2013, 2013.

Magaña, V.: Los impactos de El Niño en México, Universidad Nacional Autónoma de México y Secretaría de Gobernación, 229 pp., 1998.

Magaña, V., Pérez, J., and Conde, C.: El fenómeno de El Niño y la Oscilacion del sur (ENOS) y sus impactos, Ciencias, 14-18, 1998.

Magaña, V., Vázquez, J., Pérez, J., and Pérez, J.: Impact of El Niño on precipitation in México, Geofís. Int., 42, 313-330, 2003.

Manson, S. and Goddard, L.: Probabilistic precipitation anomalies associated with ENSO, B. Am. Meteorol. Soc., 82, 619-638, 2001.

Montealegre, J. and D. Pabón: La Variabilidad Climática Interanual asociada al ciclo El Niño-La Niña-Oscilación del Sur y su efecto en el patrón pluviométrico de Colombia, Meteorología Colombiana, 2, 7-21, 2000.

Mosiño, P. and Morales, T.: Los ciclones tropicales, El Niño y las lluvias en Tacubaya, D.F., Geofís. Int., 27, 61-82, 1998.

NOAA/National Weather Service: Cold \& Warm Episodes by Season, Climate Prediction Center, available at: http://www.cpc.ncep.noaa.gov/products/analysis_monitoring/ ensostuff/ensoyears.shtml, last access January, 2013.
Nuñez, D. and Treviño, E.: Spatial interpolation of monthly mean precipitation in the Rio Bravo/Grande basin, Tecnología y ciencias del agua, 4, 185-193, 2013.

Pereyra, D., Bando, U., and Natividad, M.: Influencia de La Niña y El Niño sobre la precipitación de la ciudad de Villahermosa, Tabasco, México, Universidad y Ciencia, 20 33-38, 2004.

Pineda, L., Ntegeka, V., and Willems, P.: Rainfall variability related to sea surface temperature anomalies in a PacificAndean basin into Ecuador and Peru, Adv. Geosci., 33, 53-62, doi:10.5194/adgeo-33-53-2013, 2013.

Philander, S. G.: El Niño, La Niña, and the Southern Oscillation, 1st Edn., Academic, San Diego, CA, 293 pp., 1990.

Poveda, G.: La hidroclimatología de Colombia: una síntesis desde la escala inter-decadal hasta la escala diurna, Rev. Academia Colombiana de Ciencias, 28, 201-222, 2004.

Poveda, G., Jaramillo, M., Gil, M., Quinceno, N., and Mantilla, R.: Seasonality in ENSO related precipitation, river discharges, soil moisture and vegetations index (NDVI) in Colombia, Water Resour. Res., 37, 2169-2178, 2001a.

Poveda, G., Rave, C., and Mantilla, R.: Tendencias en la distribución de probabilidades de lluvias y caudales en Antioquia, Meteorología Colombiana, 3, 53-60, 2001b.

Puerta, O. and Carvajal, Y.: Incidencia de El Niño-Oscilacion del Sur en la precipitación y la temperatura del aire en Colombia, utilizando el Climate Explorer, Ingenieria y Desarrollo, 23, 104 118, 2008.

Ramírez, V. and Jaramillo, A.: Relación entre el Índice Oceánico de El Niño y la lluvia en la región andina central de Colombia, Cenicafé, 60, 161-172, 2009.

Reyes, S. and Troncoso, R.: El Niño Oscilación del Sur y los fenómenos hidrometeorológicos en Baja California: el evento de 1997/98, Ciencia Pesquera, 15, 89-96, 2001.

Ruíz, A. and Pabón, D.: Efecto de los fenómenos de El Niño y La Niña en la precipitación y su impacto en la producción agrícola del departamento del Atlántico (Colombia), Rev. Colombiana de Geografía, 22, 35-54, 2013.

Ropelewski, C. F. and Halpert, M. S.: Global and Regional Scale Precipitation Patterns Associated with the El-Nino Southern Oscillation, Mon. Weather Rev., 115, 1606-1626, 1987.

Valdivia, C., Seth, A., Gilles, J., García, M., Jiménez, E., Cusicanqui, J., Navia, F., and Yucra, E.: Adapting to Climate Change in Andean Ecosystems: Landscapes, Capitals, and Perceptions Shaping Rural Livelihood Strategies and Linking Knowledge Systems, Ann. Assoc. Am. Geogr., 100, 818-834, 2010.

Valdivia, C., Thibeault, J., Gilles, J. L., García, M., and Seth, A.: Climate trends and projections for the Andean Altiplano and strategies for adaptation, Adv. Geosci., 33, 69-77, doi:10.5194/adgeo-33-69-2013, 2013.

Zambrano, E.: El fenómeno de El Niño y la oscilación del Sur, Acta Oceanográfica del Pacífico, 3, 195-203, 1986. 